\title{
Patients' anxiety before cardiac catheterization
}

\author{
Ansiedade em pacientes no período pré-cateterismo cardíaco
}

\author{
Leandro Loureiro Buzatto ${ }^{1}$, Suely Sueko Viski Zanei ${ }^{2}$
}

\begin{abstract}
Objective: To identify researches related to anxiety and strategies to reduce it in patients who are in the pre-cardiac catheterization period. Methods: A bibliographic research was carried out in the on line databases of PubMed, MedLine, CINAHL, LILACS and SciELO, from 1997 to 2009 in MedLine and from 1999 to 2009 in the others databases. The boolean expressions "and" and "or" has been used with the descriptors in Portuguese and in English. The inclusion of discerning was related about the presence, level and workable of the anxiety from the period of pre-cardiac catheterization. Results: Coping most of 17 researches selected were in American scientific publications, with experimental-descriptive studies. The possibilities of intercurrence and/or complications during and post-procedure, diagnostic, possibility of bad prognostic, being alone during the waiting, the first time submission the procedure, lost information and/or orientation and long time waiting could cause anxiety in precardiac catheterization. Maintenance of escort and family alongside the patient, information adapted to the patient understanding level, overcoming traumas and difficulties with a multiprofessional approach, pharmacologic and non pharmacologic therapies were strategies to reduce the anxiety. Conclusions: The nurses are responsible to provide a humanized assistance to offer a fast recuperation, minimize traumas of the hospitalization and the procedure. The knowledge of the causes and the strategies are fundamental to reduce the level of anxiety in pre-catheterization cardiac.
\end{abstract}

Keywords: Heart catheterization; Anxiety; Angiography; Nursing care; Humanization of assistance

\section{RESUMO}

Objetivo: Identificar pesquisas relacionadas à ansiedade e as estratégias para minimizá-la em pacientes no período pré-cateterismo cardíaco. Métodos: Revisão bibliográfica realizada no sistema de base de dados on-line PubMed, MedLine, CINAHL, LILACS e SciELO, compreendendo o período de 1997 a 2009 na MedLine e de 1999 a 2009 nas demais bases de dados. Foram utilizadas as expressões booleanas "and" e "or" combinando os termos no idioma português e inglês. Os critérios de inclusão foram estar relacionados à presença, ao nível ou ao manejo da ansiedade pré-cateterismo cardíaco. Resultados: Dentre as 17 pesquisas selecionadas, verificou-se maior número de publicações em revistas americanas, com estudos do tipo experimental-descritivo. As possibilidades de intercorrências e/ou complicações durante e após 0 procedimento, diagnóstico, possibilidade de mal prognóstico, falta de acompanhante, a primeira vez ao qual é submetido ao procedimento, a falta de informação e/ou orientação e o tempo de espera são as principais causas de ansiedade pré-cateterismo cardíaco. A manutenção dos acompanhantes e familiares junto ao paciente, as informações precoces adaptadas ao nível de entendimento, a superação de traumas e dificuldades com uma abordagem multiprofissional, as terapias farmacológicas e não farmacológicas são estratégias para redução de ansiedade. Conclusões: Os enfermeiros são responsáveis por proporcionar uma assistência humanizada, preparando o paciente afim de gerar uma recuperação mais breve, minimizando os traumas da hospitalização e do procedimento. 0 conhecimento das causas e das estratégias é fundamental para reduzir o nível de ansiedade no período pré-cateterismo cardíaco.

Descritores: Cateterismo cardíaco; Ansiedade; Angiografia; Cuidados de enfermagem; Humanização da assistência

\section{INTRODUCTION}

Cardiovascular diseases are chronic degenerative diseases causing worldwide concern due to their high incidence in several age groups ${ }^{(1)}$. Recent studies showed that cardiovascular diseases account for $32 \%$ of deaths in $\mathrm{Brazil}^{(1)}$. With the development of hemodynamic studies and interventional and diagnostic techniques, the mortality rate of coronary heart diseases decreased significantly ${ }^{(2)}$.

Presently, heart catheterization is the most used hemodynamic interventional and diagnostic technique worldwide and accounts for approximately six thousand procedures per one million inhabitants, per year, in Western counties. The complication and restenosis rates are low ${ }^{(3-5)}$.

Cardiac catheterization is the insertion of a catheter up to the aorta and left ventricle by puncturing the

\footnotetext{
'Nurse at Hospital Israelita Albert Einstein - HIAE, São Paulo (SP), Brazil.

${ }^{2}$ PhD; Nurse at Universidade Federal de São Paulo - UNIFESP, São Paulo (SP), Brazil.

Corresponding author: Leandro Loureiro Buzatto - Rua Padre Giusepe Angelo Bertoli, 1 - Centro - CEP 06600-000 - Jandira (SP), Brasil - Tel.: 11 4619-7433 - e-mail: sbztto@hotmail.com

Received on: Sep 26, 2009 - Accepted on: Apr 12, 2010
} 
brachial or femoral artery. Images of the coronary arteries are shown by injecting contrast through the catheter. This procedure is used for diagnostic assessment to confirm or determine the extent and severity of the cardiopathy ${ }^{(5,6)}$.

Although being the test of choice to diagnose and treat coronary disease, it still presents potential risks, such as arrhythmias, embolism, neurologic alterations, vasovagal changes, in addition to ischemic, allergic and vascular complications ${ }^{(6,7)}$.

Cardiac catheterization is generally an elective procedure in which a symptomatic patient with heart disease follows a protocol that requires admission to hospital $^{(7)}$.

Waiting for the procedure can be a major source of stress and anxiety. These feelings are directly related to the invasive nature of the procedure and to uncertainties related to diagnosis ${ }^{(8)}$.

In daily practice it is observed that patients do not understand clearly information given by the healthcare team due to stress and anxiety. In this context of waiting and anxiety, relatives are also stressed and share feelings and uncertainties with the patients, thus turning the situation more complex for the nursing team, since these experiences are mainly witnessed by nurses.

In the daily routine, nurses find it difficult to deal with patients' and relatives' anxiety in the pre-catheterization period. This may be justified or worsened by the lack of specific nursing standards related to family support ${ }^{(8)}$.

In face of this situation, nurses should get the best pieces of information available to deliver a better care, thus diminishing the stressing factors to reduce patients' and relatives' anxiety ${ }^{(8-9)}$.

\section{OBJECTIVE}

To identify studies about anxiety and strategies to minimize it during the pre-catheterization period.

\section{METHODS}

\section{Search and bibliographic identification}

This is a literature review using the online database systems PubMed, MedLine, CINAHL, LILACS, and SciELO.

At the PubMed, the articles were identified by using the keywords "cardiac catheterization" and "anxiety". The advanced search form with the following limits was used: "added to and published in the last 10 years to PubMed", "clinical trial", "meta-analysis", "practice guideline", "randomized controlled trial", "review", "all adult: 19+ years". The languages selected were English, French, Spanish and Portuguese.
At MedLine, the keywords were "coronary, angiography" and "anxiety", limited to the interval 19972009. This time interval was kept since in this database there is no other option. At LILACS and SciELO, the search keywords were "cardiac catheterization" and "anxiety" (in Portuguese). At CINAHL, the keywords were "cardiac catheterism" and "anxiety".

To select journals, the Boolean expressions "and" \& "or" were used with the combined terms "cardiac catheterization (and) anxiety". In English, the combined terms used were "cardiac catheterization (and) anxiety", "angiography (or) cardiac catheterization (and) anxiety".

At PubMed, 18 studies were identified and 5 were selected. At MedLine, 41 studies were found and 8 articles about pre-catheterization anxiety were selected.

At LILACS, five studies were found and two were selected. At SciELO, three investigations were found and two articles related to pre-catheterization anxiety level were chosen. At CINAHL, there were 38 articles and 2 were related to the theme of this study.

The bibliographic search comprised the period from 1997 to 2009 at the MedLine and from 1999 to 2009 at the other databases.

\section{Selection criteria}

The following inclusion criteria were used in the study: to be related to the issue of anxiety, level of anxiety or anxiety management in patients before cardiac catheterization. After search, the articles not related to the core issue or to the objectives of the study were excluded. The studies were first identified through reading and analysis of titles and abstracts, and the selected studies were assessed in full text.

\section{RESULTS}

The selected studies are presented in Table 1, per journal, country of origin and type of study. There are more publications on experimental studies performed in the United States (41.17\%), followed by Brazil $(23.52 \%)$ and other countries $(35.1 \%)$. The topics addressed were related to presence of anxiety or its severity, as well as management of anxiety in patient before catheterization.

Most articles had been published in American journals, followed by Brazilian publications. Most studies were experimental-descriptive and only two were literature reviews. Most journals are related to nursing. This may show the need of nurses to get answers to their daily work questions when dealing with anxiety of patients and relatives before cardiac catheterization. 
Table 1. Studies related to presence, intensity or management of anxiety in patients before cardiac catheterization. São Paulo, 2009

\begin{tabular}{|c|c|c|c|c|c|c|c|}
\hline \multirow{2}{*}{ Journal } & \multirow{2}{*}{ Authors } & \multirow{2}{*}{ Year } & \multirow{2}{*}{ Origin } & \multicolumn{3}{|c|}{ Type of study } & \multirow{2}{*}{$\mathbf{N}$} \\
\hline & & & & A & B & C & \\
\hline Arquivos Brasileiros de Cardiologia & $\begin{array}{l}\text { Guerios EE, Bueno RRL, Andrade PMP, Nercolini DC, } \\
\text { Pacheco ALA? }\end{array}$ & 1998 & Brazil & 1 & & & 1 \\
\hline Journal of Vascular Nursing & Mott $\mathrm{AM}^{21}$ & 1999 & United States & 1 & & & 1 \\
\hline Intensive and Critical Care Nursing & Hamel WJ19 & 2001 & United States & & 1 & & 1 \\
\hline Journal of Cardiovascular Nursing & Chan DSK, Cheung HW'16 & 2003 & United States & 1 & & & 1 \\
\hline European Journal of Cardivascular Nursing & Harkness K, Morrow L, Smith K, Kiczula M, Arthur HM'15 & 2003 & United States & & 1 & & 1 \\
\hline Revista Latino Americana de Enfermagem & Grazziano ES, Bianchi ER ${ }^{8}$ & 2004 & Brazil & & 1 & & 1 \\
\hline Revista Psico & Padilha RV, Kristensen $\mathrm{CH}^{18}$ & 2006 & Brazil & 1 & & & 1 \\
\hline Brazilian Journal of Nursing & Lourenci R, Andrade M"11 & 2006 & Brazil & & & 1 & 1 \\
\hline Revista Brasileira de Enfermagem & Freitas MC, Oliveira MF9 & 2006 & Brazil & & & 1 & 1 \\
\hline Heart \& Lung & $\begin{array}{l}\text { Ulvik B, Bjelland I, Henestad BR, Omenaas E, Learsen TW, } \\
\text { Nygard } 0^{10}\end{array}$ & 2008 & Norway & & 1 & & 1 \\
\hline Journal of Clinical Nursing & Uzun S, Vural H, Uzun M, Yokusoglu M ${ }^{13}$ & 2008 & Turkey & 1 & & & 1 \\
\hline Texas Heart Institute Journal & Vural M, Satiroglu O, Akbas B, Goksel I, Karabay $0^{14}$ & 2009 & United States & & 1 & & 1 \\
\hline Total & & & & 7 & 8 & 2 & 17 \\
\hline Percentage & & & & $41.18 \%$ & $47.06 \%$ & $11.76 \%$ & $100 \%$ \\
\hline
\end{tabular}

\section{DISCUSSION}

Cardiac catheterization is a common interventional diagnostic procedure used in patients with acute coronary syndrome (ACS). It can cause several complications that have to be identified and treated after the test ${ }^{(6)}$. Taking into account possible complications, healthcare professionals pay close attention to their patients after catheterization. However, the pre-catheterization also deserves a differentiated care by the multidisciplinary team, especially by nurses, who are responsible for preparing the patient and giving them advice; nurses are closer to the patients at this time ${ }^{(8)}$.

This period is characterized by the expression of several emotions by both patients and their relatives or friends. In $15 \%$ of patients, depression or fear was expressed or verbalized. Anguish was found in approximately $30 \%$ of patients and the remaining $65 \%$ mentioned anxiety ${ }^{(10)}$.

Anxiety is a common emotion before cardiac catheterization. Although more catheterizations are performed in men, many studies mention that women are more affected by anxiety. According to some studies, the incidence in women ranged from 30 to $55 \%$. Fortyfive percent of females present mild anxiety and $40 \%$ have moderate anxiety ${ }^{(8,10,11)}$.

Not only patients feel anxiety; $80 \%$ of female relatives or friends mentioned different levels of anxiety. In $52 \%$ of these relatives, the anxiety level was moderate and $40 \%$ showed mild anxiety ${ }^{(8)}$. However, the same study showed that severe anxiety was two times higher in patients than in relatives ${ }^{(8)}$.

In another study in which anxiety prevailed in males $(63 \%)$, severe anxiety was also present. Therefore, although more affected, female patients have milder anxiety than male patients ${ }^{(12)}$.

\section{Factors that trigger anxiety}

Patients' anxiety has several causes. In a recent study, anxiety before cardiac catheterization is related to both concerns about intercurrent events and/or complications during or after the procedure, diagnosis and a possible poor prognosis ${ }^{(13,14)}$.

Other issues can also increase the incidence of anxiety. Patients mentioned absence of companions, first time they are submitted to the procedure, lack of information and/or satisfactory orientation, and especially waiting time are important determinants of anxiety ${ }^{(13-15)}$.

The waiting time before cardiac catheterization is directly proportional to anxiety episodes and levels, i.e., the greater the waiting time, the higher the anxiety level ${ }^{(15)}$. There are no studies showing anxiety levels of relatives or companions during the waiting period, but it is known to be similar to anxiety before surgical procedures $^{(8)}$. Separation from the patient is the greatest source of anxiety ${ }^{(8)}$. And information provided to patients is inversely proportional to anxiety: the lesser the amount of information, the greater the anxiety ${ }^{(15)}$. 


\section{Strategies used to minimize anxiety}

Having identified the triggering factors of anxiety, there is a decrease in its incidence when waiting time before cardiac catheterization is reduced ${ }^{(15,16)}$. The presence of relatives or friends before the test also reduces anxiety of both patients and relatives ${ }^{(8,15,16)}$.

Although the influence of the environment where patients and relatives wait has not been mentioned in studies, there is evidence that a place offering some distraction and providing information reduces anxiety levels ${ }^{(15,16)}$.

There is evidence that information offered by nurses at an early stage also reduces anxiety ${ }^{(16)}$.

When giving information to patients and relatives, nurses have several choices. They can use folders, posters or educational videos to make information clear and easily understandable ${ }^{(16,17)}$.

None of the tools used by nurses was better or more efficient than the others. All tools reduced patients' and relatives' anxiety, if presented early and clearly, adjusted to their level of understanding ${ }^{(15,17)}$.

Anxiety is reduced when better quality information and more contents are provided. This happens when nurses are able to clear patients' and relatives' doubts, joining technical information to sensory-perceptive explanation ${ }^{(15-17)}$.

When the nurse explains theoretical issues, adapting them to patients' level of understanding and using one or more illustration strategies to make patients understand what are the stages of the procedure, results are better ${ }^{(16,17)}$.

Another strategy to reduce anxiety before cardiac catheterization is psychoeducational technique that aims to minimize it and help patients understand their fears and mechanisms that trigger anxiety ${ }^{(8)}$.

In a multidisciplinary approach, nurses and psychologists talk to patients trying to reduce their anxiety by explaining the procedure to be performed ${ }^{(18)}$. Among alternative techniques to reduce anxiety before cardiac catheterization, music therapy is one of the most studied methods. It uses music as non-pharmacologic treatment aiming to provide comfort, wellbeing, and relaxation by affective, cognitive, and sensorial stimuli ${ }^{(19)}$.

Some studies show that music therapy is an efficient technique to decrease anxiety before cardiac catheterization. Heart rate and blood pressure reduction are observed after music therapy ${ }^{(19)}$. For greater efficacy of music therapy, patients should be given options, but mainly slow music, such as classical or relaxation music should be offered. Patients decide what they want to listen and at which volume. Some studies reported satisfactory results after 20 to 40 minutes of therapy ${ }^{(19,20)}$.
With the introduction of music therapy, a $15 \%$ reduction in anxiety was seen. According to patients, music therapy was important because it helped to "spend time", thus eliminating a major cause of anguish and anxiety: the waiting time before the procedure $^{(19,20)}$.

When compared to pharmacologic interventions as sedatives given 30 minutes before the procedure, music therapy was less effective ${ }^{(20,21)}$.Some studies mentioned that sedatives reduce and control anxiety before cardiac catheterization. Sedatives also act on other symptoms, such as pain ${ }^{(21)}$. Thus, both treatments are effective in reducing these patients' anxiety; results are even better when they are combined ${ }^{(19-21)}$.

Independently of the treatment chosen, nurses should address both patients and relatives. There is evidence that patients' anxiety decreases when their relatives or friends are calmer ${ }^{(8,20,21)}$.

\section{FINAL CONSIDERATIONS}

Nurses responsible for cardiac catheterization should know the causes of anxiety and strategies to reduce it. By delivering humanized care, nurses must aim to prepare the patients for a shorter recovery time, minimizing procedure and hospitalization trauma.

According to the literature, pre-catheterization anxiety is caused by intercurrent events and/or complications during or after the procedure, the diagnosis and a bad prognosis.

Anxiety is also related to the absence of relatives, friends or other companions, to the first time the patient undergoes the procedure, lack of information and/or advice, and, mainly, to waiting time.

\section{CONCLUSION}

Among the strategies to reduce anxiety the most efficient are as follows: to keep relatives or other companions as long as possible close to the patient, to offer information suitable to the patients' level of understanding as early as possible, to overcome traumas or special difficulties by means of a multidisciplinary approach, and to use non-pharmacological treatments as music therapy and sedatives.

\section{REFERENCES}

1. Lessal, organizador. 0 adulto brasileiro e as doenças da modernidade: epidemiologia das doenças crônicas não transmissíveis. São Paulo: Hucitec; 1998. Introdução à epidemiologia das doenças cardiovasculares no Brasil. p. 73-6.

2. Dotter CT. Transluminally-placed coilspring endarterial tube grafts. Long-term patency in canine popliteal artery. Invest Radiol. 1969;4(5):329-32. 
3. Brito FS Jr, Ariê S, Caixeta AM, Soares PR, Obregon A, Perin MA, et al. Abordagem terapêutica da reestenose após implante de stent coronário. Rev Bras Cardiol Invas. 1997;5(1):37-46.

4. Berg KJ. Nephrotoxicity related to contrast media. Scand J Urol Nephrol. 2000;34(5):317-22.

5. Lima LR, Pereira SV, Chianca TC. Diagnósticos de enfermagem em pacientes pós-cateterismo cardíaco: contribuição de Orem. Rev Bras Enferm. 2006;59(3):285-90.

6. Rossato G, Quadros AS, Leite RS, Gottschal CA. Analysis of in-hospital complications related to cardiac catheterization. Rev Bras Cardiol Invas. 2007;15(1):44-51.

7. Guérios EE, Bueno RR, Andrade PM, Nercolini DC, Pacheco AL. Stents. Uma revisão da literatura. Arq Bras Cardiol. 1998;71(1):77-87.

8. Grazziano ES, Bianchi ER. Nível de ansiedade de clientes submetidos a cineangiocoronariografia e seus acompanhantes. Rev Lat-Am Enf. 2004;12(2):168-74.

9. Freitas MC, Oliveira MF. Assistência de enfermagem a idosos que realizam cateterismo cardíaco: uma proposta a partir do modelo de adaptação de Calista Roy. Rev Bras Enferm. 2006;59(5):642-6.

10. Ulvik B, Bjelland I, Henestad BR, Omenaas E, Wentzel-Learsen T, Nygard O. Comparison of the short form 36 and the hospital anxiety and depression scale measuring emotional distress in patients admitted for elective coronary angiography. Heart Lung. 2008;37(4):286-95.

11. Lourenci RB. Sistematização da assistência de enfermagem ao paciente submetido ao cateterismo cardíaco: análise da produção científica. Online Braz J Nurs [Internet]. 2006 citado 2010 Nov 23] ;5(3). Disponível em: www. uff.br/nepae/objn.
12. Heather MA. Final report. Reducing anxiety in patients awaiting elective cardiac catheterization [Internet] Nov 2003 [cited 2010 Jan 20]. Available at: http:// www.canadiannursesfoundation.com/documents/ArthurNov2003reportEng.pdf

13. Uzun $S$, Vural $H$, Uzun M, Yokusoglu M. State and trait anxiety levels before coronary angiography. J Clin Nurs. 2008;17(5):602-7.

14. Vural M, Satiroglu O, Akbas B, Goksel I, Karabay 0 . Coronary artery disease in association with depression or anxiety among patients undergoing angiography to investigate chest pain. Tex Heart Inst J. 2009;36(1):17-23.

15. Harkness K, Morrow L, Smith K, Kiczula M, Arthur MH. The effect of early education on patient anxiety while waiting for elective cardiac catheterization. J Cardiovasc Nurs. 2003;2(2):113-21.

16. Chan DS, Cheung HW. The effects of education on anxiety among Chinese patients with heart disease undergoing cardiac catheterization in Hong Kong. Contemp Nurse. 2003;15(3):310-20.

17. Philippe F, Meney M, Larrazet F, Ben Abderrazak F, Dibie A, Meziane T, et al. Effects of video information in patients undergoing coronary angiography. Arch Mal Coeur Vaiss. 2006;99(2):95-101.

18. Padilha RV, Kristensen $\mathrm{CH}$. Estudo exploratório sobre o medo e ansiedade em pacientes submetidos ao cateterismo cardíaco. Psico (Porto Alegre). 2006;37(3):233-40.

19. Hamel WJ. The effects of music intervention on anxiety in the patient waiting for cardiac catheterization. Intensive Crit Care Nurs. 2001;17(5):279-85.

20. Bally K, Campbell D, Chesnick K, Tranmer JE. Effects of patient-controlled music therapy during coronary angiography on procedural pain and anxiety distress syndrome. Crit Care Nurs. 2003;23(2):50-7.

21. Mott AM. Psychologic preparation to decrease anxiety associated with cardiac catheterization. J Vasc Nurs. 1999;17(2):41-9. 